\title{
STUDIES ON TRITIUM-LABELED DIGOXIN: TISSUE, BLOOD AND URINE DETERMINATIONS
}

\author{
By LUIS F. GONZALEZ * AND ENNIS C. LAYNE $\dagger$ \\ (From the Department of Medicine and Pediatrics, University of Maryland School of Medi- \\ cine, and the University Hospital, Baltimore, $M d$. \\ (Submitted for publication February 11, 1960 ; accepted June 11, 1960)
}

During the last 40 years extensive investigations have been reported on various aspects of the metabolism of cardiac glycosides. A detailed review describing the cellular basis of cardiac glycoside action has been reported by Hajdu and Leonard (1). One prime difficulty encountered in determining the metabolic fate of cardiac glycosides is in establishing a reliable and sensitive method for determining tissue, blood and urine levels of the glycosides as well as their derivatives in man and in experimental animals. The minute amounts present in blood, urine and tissues after oral or parenteral administration require extremely sensitive assay methods. Digitalis glycosides have been studied by utilizing bioassay (2-9), colorimetric (10-14), radioisotopic (15-17), and polarographic techniques $(18,19)$.

The behavior and fate of digitoxin in experimental animals and in man have been reviewed by Friedman, St. George and Bine (20). In Friedman's laboratory, bioassay techniques using embryonic duck hearts have detected $0.1 \mu \mathrm{g}$ of digitoxin per $\mathrm{ml}$ of serum of humans who received 1.2 $\mathrm{mg}$ digitoxin intravenously (21). The method consists of the observation of cardiac irregularities in embryonic duck hearts immersed in test fluids $(8,22)$. This group has reported reproducible results in studies of experimental animals and humans $(8,20,22-30)$.

Digitoxin labeled with carbon ${ }^{14}$ has been shown to be an excellent tool for appraising the behavior and fate of the glycoside $(15-17,31-38)$. Studies utilizing carbon ${ }^{14}$ digitoxin have included the fixation of cardioactive glycosides by isolated hearts (15) ; the tissue distribution and excretion in digitalis-sensitive and digitalis-resistant animals (16) ;

\footnotetext{
* U.S.P.H.S. Postdoctoral Research Fellow in Cardiology, University of Maryland School of Medicine.

† Instructor in Pediatrics and Assistant Professor of Biochemistry, University of Maryland School of Medicine.
}

the placental transfer of digitoxin in rats and guinea pigs (32) ; the renal excretion (33), blood levels (17), metabolic fate (34), and the placental transfer and fetal distribution (36) in humans.

The advantages of radioactive tracer methods for investigating the metabolic fate of digitoxin have been discussed by Sjoerdsma, Fischer and Johnson $(15,16)$, Okita and co-workers (17), and Geiling and Okita and co-workers (31-34, 36). The incorporation of a tracer substance with a higher maximal permissible radioactivity dose than that of carbon ${ }^{14}$ would make it possible to study various aspects of the metabolic pathways of the parent compound in greater detail. Thus it would be feasible to perform long-term studies in humans utilizing the radioactive glycoside exclusively. Data obtained from acute experiments carried out in laboratory animals might be correlated with results in humans. Recently, tritium-labeled digoxin (digoxin- $\left.\mathrm{H}^{3}\right)^{1}$ became available for experimental use. Extensive data on the utilization of tritium-labeled compounds were presented at three annual symposia in New York City $(39,40)$. The physiology and toxicology of tritium in man were studied extensively by Pinson and Langham (41).

This report presents preliminary data from studies in dogs using digoxin- $\mathrm{H}^{3}$ administered intravenously.

\section{EXPERIMENTAL METHOD}

Unselected mongrel dogs weighing between 12 and $25 \mathrm{~kg}$ were anesthetized with Pentothal Sodium administered intravenously without prior medication. An endotracheal tube was inserted and respirations were assisted with a Phipps-Bird type respirator. Utilizing routine surgical techniques, polyethylene cannulas were inserted into a contralateral femoral artery and vein for the collection of blood samples. A superficial foreleg vein was cannulated for the administration of fluids and

1 Dr. Stanley T. Bloomfield, Burrough Wellcome, Ltd., kindly supplied the radioactive digoxin. 


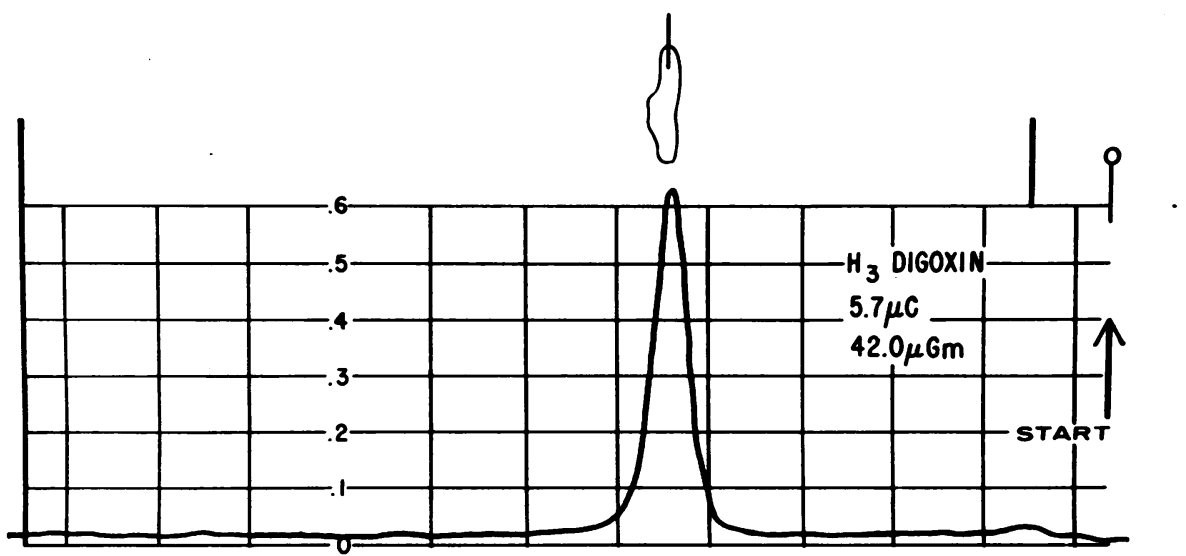

Fig. 1. Counting Record of a chromatographic spot containing $42 \mu \mathrm{g}$ of DIGOXIN-H $\mathrm{H}^{3}(5.7 \mu \mathrm{C}$ OF TRITIUM $)$. Peak of radioactivity coincides with area of digoxin concentration.

drugs. The remaining superficial femoral artery was cannulated for recording intra-arterial blood pressures with a Statham pressure transducer. Needle electrodes were inserted and standard extremity electrocardiographic leads were recorded. Polyethylene catheters were introduced into the urinary bladder with 13 gage hypodermic needles or through a cystostomy wound. The right chest cavity was entered at the fourth intercostal space. The pericardium was incised and sutured to the chest wall. A purse string suture was placed on the right auricular appendage and a polyethylene catheter was guided into the coronary sinus. A transfixing suture was used to sustain the catheter in the coronary sinus with careful avoidance of blockage to the coronary sinus. The patency of the various catheters was maintained by a constant flow of heparinized saline. The arterial catheters were washed at repeated intervals with heparinized saline. Digoxin- $\mathrm{H}^{3}$, and digoxin injection (Lanoxin) were mixed with 0.9 per cent saline in a syringe in the amounts specified in Table I: The tritiumlabeled digoxin was made available in ampules containing $1 \mathrm{mg}$ of digoxin labeled with $134 \mu \mathrm{c}$ of tritium. The suspension was administered intravenously over one minute.

In order to make simultaneous collections, the serial collections from each blood vessel were made by three observers. Unless otherwise specified, samples were collected at 1, 3, 5, 10, 15, 30, 45 and 60 minutes after drug administration. Biopsy specimens were obtained from the right atrium and ventricle at predetermined intervals. Double mattress sutures were placed at the surgical site. At the termination of each experiment the animal was sacrificed. The liver, kidneys and heart were removed, weighed, and representative samples obtained. Total urine specimens were collected at various time intervals for measurement. The amount of fluid administered intravenously was determined for each study. Throughout the experiments, intra-arterial pressures and electrocardiograms were monitored and recorded.

\section{Preparation of samples for determination of radioactivity}

1. Blood. Ten $\mathrm{ml}$ of 95 per cent ethanol was added to $1 \mathrm{ml}$ of heparinized blood in order to precipitate the protein. This was then centrifuged for 10 minutes at 2,500 rpm. Two $\mathrm{ml}$ of the clear supernate was removed and evaporated to dryness. The residue was dissolved in 0.4 $\mathrm{ml}$ of 95 per cent ethanol. Two-tenths $\mathrm{ml}$ was mixed with $15.0 \mathrm{ml}$ of a solution made by mixing $0.01 \mathrm{~g}$ bisphenyloxazolylbenzene (a wavelength shifter), $0.20 \mathrm{~g} \mathrm{2,5}$ diphenyloxazole (a phosphor), and $100.0 \mathrm{ml}$ toluene. The samples were transferred to special counting vials and cooled in a freezer at $0^{\circ} \mathrm{C}$ for at least 24 hours. All samples were counted in a Packard Tri-Carb liquid scintillation spectrometer with a two-channel pulse-height analyzer. This instrument was calibrated daily, utilizing a standard containing $134 \mathrm{~m} \mu \mathrm{c}$ of tritium-labeled digoxin. All samples were counted for 1 hour. Unless otherwise specified, counts were expressed in millimicrocuries per gram of tissue. Recovery experiments were performed by adding digoxin- $\mathrm{H}^{3}$ to blood and extracting as indicated. Approximately 95 to 98 per cent of the added radioactivity was recovered by the procedure used.

2. Urine. The urine samples were diluted with 95 per cent ethanol to a final dilution of $1: 2$. Two $\mathrm{ml}$ was evaporated to dryness and the residue treated as described above.

3. Tissues. The tissue samples were dried with filter paper to remove blood and extracellular fluid. They were weighed, and preserved in $5.0 \mathrm{ml}$ of 95 per cent ethanol until homogenized. Two $\mathrm{ml}$ of the homogenate was removed, evaporated to dryness, and treated as described above.

\section{Chromatographic studies}

Chromatographic studies were performed, using multiple solvent systems (see below) to identify the glycoside or its metabolites in urine and blood. These studies were necessary, since the concentration of radioactive material in blood and urine does not necessarily indicate 
the presence of unaltered digoxin $\mathrm{H}^{3}$. Control chromatographic observations were performed using alcoholic solutions of radioactive and nonradioactive digoxin, and mixtures of these solutions with blood and urine in multiple proportions (42). Urine samples were precipitated with 40 per cent lead acetate and the supernate was extracted three times with chloroform ( 3 parts chloroform to 1 part urine). The chloroform extract was evaporated to dryness, and the residue dissolved in a $1: 1$ chloroform: methanol solution. This final suspension was evaporated to a small volume and examined with chromatographic techniques. Details of these techniques are given by Gisvold and Wright (43).

Chromatographic studies of digoxin solutions were carried out utilizing the following solvent systems: 1) chloroform-benzene-formamide $(44)$; 2) chloroformwater-methanol (44); 3) benzene-chloroform-butanol (45) ; 4) benzene-ethyl acetate-chloroform (46); 5) methyl-isobutylketone-isopropyl ether-formamide (43). Optimal results were obtained with a slight modification of system 5. The proportions by volume were: methylisobutylketone, 8 ; isopropyl ether, 2 ; butanol, 1 ; and formamide, q.s. to saturate.

The chromatographic strips were allowed to develop in a closed jar saturated with the solvent system described. They were then passed quickly through a solution of 2.5 per cent meta-dinitrobenzene in chloroform and sprayed with a solution of 5 per cent $\mathrm{KOH}$ in methanol. The strips were examined under white and ultraviolet light. The $\mathrm{Rf}$ values were calculated for each chromatogram. The spots were sectioned off the paper, eluted with isopropanol, and processed for radioactivity counting as described previously.

\section{EXPERIMENTAL RESULTS}

Blood levels of digoxin- $H^{3}$. Blood samples aspirated simultaneously from the femoral artery, femoral vein and coronary sinus showed a rapid decrease in radioactivity during the first $15 \mathrm{~min}$ utes (Table II).

Urine levels of digoxin- $H^{3}$. Significant levels of the radioactive isotope were measured in the urine samples collected within 30 minutes after the intravenous injection of tritium-labeled digoxin (Table III).

TABLE

Digoxin dose schedule

\begin{tabular}{ccccc}
\hline \hline Dog & Weight & Digoxin-H & Lanoxin & $\begin{array}{c}\text { Vol. of } \\
\text { injection }\end{array}$ \\
\hline & $k g$ & $m g$ & $m g$ & $m l$ \\
1 & 25.0 & 0.5 & 0.125 & 5.0 \\
2 & 12.7 & 1.0 & 0.5 & 10.0 \\
3 & 13.6 & 1.0 & 1.0 & 10.0 \\
4 & 18.1 & 1.0 & 1.0 & 10.0 \\
5 & 10.9 & 2.0 & 0.5 & 10.0
\end{tabular}

TABLE II

Blood levels of digoxin- $H^{3}$

\begin{tabular}{|c|c|c|c|c|}
\hline Dog & Time & Arterial & Venous & $\begin{array}{c}\text { Coronary } \\
\text { sinus }\end{array}$ \\
\hline \multirow{7}{*}{1} & $\min$ & & $m \mu c / m l$ blood & \\
\hline & 1 & 184.14 & 49.84 & 117.56 \\
\hline & 3 & 54.82 & 19.58 & 28.58 \\
\hline & 5 & 34.90 & 13.34 & 21.40 \\
\hline & 10 & 15.24 & 10.82 & 8.74 \\
\hline & 23 & 8.88 & 7.34 & 4.60 \\
\hline & 45 & 4.02 & 4.04 & 1.8 \\
\hline \multirow[t]{10}{*}{2} & 1 & 181.48 & 167.24 & 86.24 \\
\hline & 3 & 81.56 & 75.38 & 96.94 \\
\hline & 5 & 30.98 & 64.92 & 65.92 \\
\hline & 10 & 26.92 & 41.64 & 43.06 \\
\hline & 15 & 30.20 & 31.92 & 26.66 \\
\hline & 30 & 15.44 & 14.32 & 14.46 \\
\hline & 45 & 8.90 & 9.44 & 5.56 \\
\hline & 60 & 10.60 & 7.80 & 10.26 \\
\hline & 75 & 6.14 & 9.02 & 6.60 \\
\hline & 90 & 4.46 & 4.64 & 4.20 \\
\hline \multirow[t]{8}{*}{3} & 1 & 238.30 & 153.40 & 158.20 \\
\hline & 3 & 129.12 & 77.70 & 103.92 \\
\hline & 5 & 112.02 & 60.16 & 79.94 \\
\hline & 10 & 65.80 & 53.14 & 42.24 \\
\hline & 15 & 26.80 & 34.26 & 38.50 \\
\hline & 25 & 17.36 & 21.02 & 19.32 \\
\hline & 35 & 12.32 & 17.14 & 13.26 \\
\hline & 38 & 10.78 & 18.20 & 19.14 \\
\hline \multirow[t]{8}{*}{4} & 1 & 149.14 & 132.44 & 151.00 \\
\hline & 3 & 69.26 & 80.16 & 105.46 \\
\hline & 5 & 70.70 & 59.92 & 47.06 \\
\hline & 10 & 47.58 & 47.38 & 36.86 \\
\hline & 15 & 21.48 & 34.08 & 30.84 \\
\hline & 30 & 26.82 & 27.72 & 15.04 \\
\hline & 45 & 10.12 & 16.94 & 12.12 \\
\hline & 60 & 12.44 & 12.48 & 12.70 \\
\hline \multirow[t]{7}{*}{5} & 1 & 324.00 & 119.58 & 199.82 \\
\hline & 3 & 193.08 & 97.38 & 208.52 \\
\hline & 5 & 90.24 & 214.32 & 142.18 \\
\hline & 10 & 38.64 & 165.58 & 83.88 \\
\hline & 15 & 20.38 & 66.78 & 29.90 \\
\hline & 30 & 37.52 & 16.76 & 26.42 \\
\hline & 45 & 8.70 & 19.98 & 32.58 \\
\hline
\end{tabular}

Tissue levels of digoxin- $H^{3}$. Studies of the tissue levels of the isotope revealed significant amounts of radioactive digoxin in the liver, kidneys and heart. In tissue samples obtained at the end of the experiment, the highest concentration of radioactive digoxin per gram of tissue was found in the kidney. An average of $633.40 \mathrm{~m} \mu \mathrm{c}$ was recovered per $g$ of kidney. Studies of liver and heart revealed an average recovery of 128.48 and $72.35 \mathrm{~m} \mu \mathrm{c}$ per $\mathrm{g}$ of tissue, respectively (Table IV). An average of 68.73 per cent of the total administered radioactive digoxin was recovered in the liver, heart and kidneys (Table V). These three organs accounted for an average of 4.1 per cent of the dog's body weight. 
TABLE III

Recovery of digoxin- $\mathrm{H}^{3}$ in urine

\begin{tabular}{|c|c|c|c|c|}
\hline Dog & $\begin{array}{l}\text { Time interval } \\
\text { after i.v. } \\
\text { injection of } \\
\text { digoxin- } \mathrm{H}^{3}\end{array}$ & $\begin{array}{l}\text { Urine } \\
\text { collected }\end{array}$ & $\begin{array}{c}\text { Total } \\
\text { recovered }\end{array}$ & $\begin{array}{c}\text { Injected } \\
\text { dose }\end{array}$ \\
\hline 1 & $\begin{array}{c}\min \\
0-22 \\
22-45\end{array}$ & $\begin{array}{l}m l \\
13 \\
16\end{array}$ & $\begin{array}{c}\mu c \\
2.926 \\
2.476\end{array}$ & $\begin{array}{c}\% \\
8.06\end{array}$ \\
\hline 2 & $\begin{array}{r}0-60 \\
60-75 \\
75-85\end{array}$ & $\begin{array}{l}38 \\
44 \\
65\end{array}$ & $\begin{array}{l}2.528 \\
2.020 \\
2.870\end{array}$ & 6.28 \\
\hline 4 & $\begin{array}{r}0-10 \\
10-30 \\
30-45\end{array}$ & $\begin{array}{r}42 \\
200 \\
100\end{array}$ & $\begin{array}{l}0.125 \\
3.374 \\
5.152\end{array}$ & 6.45 \\
\hline
\end{tabular}

Chromatographic studies. Controlled chromatographic studies of digoxin solutions showed that the $\mathrm{Rf}$ values of the glycoside were not altered by chloroform extraction. Chromatographic spots, satisfactory for identification studies, have been obtained using as little as $0.006 \mathrm{mg}$ digoxin in 25 $\mu l$ of 95 per cent ethanol.

The chromatographic strips obtained by using radioactive samples were cut lengthwise and studied, utilizing a Chromatogram scanner (Baird Atomic) with rectilinear galvanometric recorder (Texas Instrument, Inc.). A representative "curve" is depicted in Figure 1. The spots were later sectioned off the paper, eluted and processed for counting as described previously (42).

\section{DISCUSSION}

A technique has been described which appears to be suitable for the appraisal of certain aspects of the metabolism of a cardiac glycoside in blood, urine and body tissues.

Forty minutes after the injection of tritium-labeled digoxin, approximately 68 per cent of the drug could be recovered from the heart, kidneys and liver. This percentage of recovery compares favorably with studies utilizing digitoxin- $C^{14}(17$,

TABLE IV

Recovery of digoxin- $H^{3}$

\begin{tabular}{crrr}
\hline \hline Dog & Heart & Kidney & \multicolumn{1}{c}{ Liver } \\
\hline & & $m \mu c / g$ tissue & \\
1 & 47.00 & 147.48 & 14.26 \\
2 & 80.30 & 899.32 & 48.40 \\
3 & 113.62 & 525.70 & 124.54 \\
4 & 64.30 & 388.34 & 82.80 \\
5 & 156.51 & $1,206.18$ & 372.44 \\
\hline
\end{tabular}

$33,34)$. The relatively large amounts of the radioactive isotope recovered in the urine and kidneys corroborate data of other investigators who have shown that the major organ involved in the ultimate excretion of digitoxin is the kidney (34). Using the chromatographic techniques described, we have been able to identify the unaltered glycoside, digoxin, in dog urine in our acute, shortterm experiments.

Both digoxin and lanatoside $\mathrm{C}$ have been found to be excreted principally as the unchanged glysoside (38). A conjugate of digoxigenin has also been identified in rat urine after the administration of digoxin and lanatoside $C(38,47)$, and in rat bile after the administration of digoxin (48). Three separate bands have been obtained in chromatographic studies of rat urine after the administration of acetyldigitoxin (47). The band closest to the starting line could not be separated from metabolite $B$, a conjugate of digoxigenin.

TABLE $V$

Recovery of digoxin- $H^{3}$ from kidneys, liver and heart

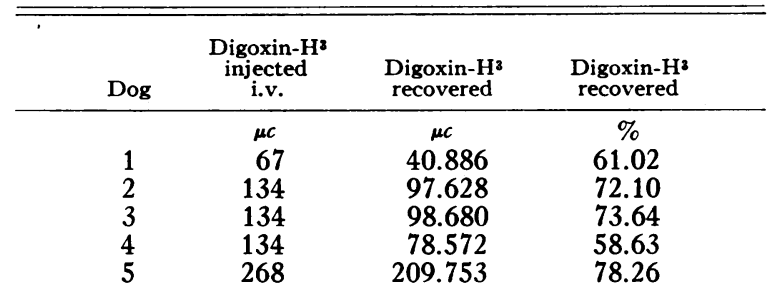

After hydrolysis this product could not be separarated from digoxigenin. A second band which could not be separated from metabolite $G$, digoxin, was also hydrolyzed to digoxigenin. Further studies are being carried out in this laboratory to identify any metabolite that may be present in dog urine after the intravenous administration of radioactive digoxin. The nature of the radioactive material present in the kidney, heart and liver is being investigated in this laboratory.

From the data presented, it is evident that measurable levels of radioactive digoxin can be determined in blood, urine, heart, kidneys and liver of dogs receiving 3 to $7 \mu \mathrm{c}$ of tritium per $\mathrm{kg}$. According to published reports (49) "the maximal permissible amount of the radioisotope in the total body is $2 \times 10^{3} \mu \mathrm{c}$." Extrapolation of the data presented in this report suggests that satisfactory 
levels of the isotope should be obtained in humans using digoxin- $\mathrm{H}^{3}$ in dosages well within the permissible radioactivity. Preliminary observations regarded as satisfactory have been obtained in studies of urine and blood samples in one human (42). Apparently, studies of the metabolic pathways of digoxin in humans over long periods of time may be performed without dangerous exposure to radiation $(50)$.

\section{SUM MARY}

Blood, urine and body tissue levels of tritiumlabeled digoxin were studied in five mongrel dogs. The isotopic concentrations were measured by the liquid scintillation technique. Utilizing chromatographic techniques, the radioactive material excreted in the urine after the intravenous administration of the drug could not be distinguished from unaltered digoxin.

\section{ACKNOWLEDGMENT}

Grateful appreciation is expressed to Dr. Stanley T. Bloomfield, Medical Director, Burroughs Wellcome, Ltd., for generous supplies of digoxin- $\mathrm{H}^{3}$ which made this study possible. We wish to thank Professor Ole Gisvold, Chairman of the Department of Pharmaceutical Chemistry, College of Pharmacy, University of Minnesota; and Dr. Leonard Scherlis, Head of the Division of Cardiology, Dr. Samuel P. Bessman, Professor of Pediatrics, Dr. Theodore E. Woodward, Head of the Department of Medicine, and Dr. Joseph B. Workman, Chief, Division of Radio-Isotopes, School of Medicine, University of Maryland, for their helpful suggestions and encouragement. Our appreciation is also expressed to Miss Evelyn Rice, and to Mr. Osmar P. Steinwald, Summer Fellow in Cardiology, University of Maryland Medical School, for their technical assistance.

\section{REFERENCES}

1. Hajdu, S., and Leonard, E. The cellular basis of cardiac glycoside action. Pharmacol. Rev. 1959, $11,173$.

2. Hatcher, R. A., and Brody, J. G. The biological standardization of drugs. Amer. J. Pharm. 1910, 82, 360 .

3. Knaff-Lenz, E. The physiological assay of preparations of digitalis. J. Pharmacol. exp. Ther. 1926, 29, 407.

4. Hall, E. M. The chick heart method of biological assay; digitalis. Amer. J. Pharm. 1932, 104, 310.

5. Cattell, McK., and Gold, H. The influence of digitalis glucosides on the force of contraction of mammalian cardiac muscle. J. Pharmacol. exp. Ther. 1938, 62, 116.
6. Paff, G. H. Micro-method for digitalis assay. J. Pharmacol. exp. Ther. 1940, 69, 311.

7. Lehman, R. A., and Paff, G. H. A practical technique and design for the assay of digitalis on the embryonic chick heart. J. Pharmacol. exp. Ther. 1942, 75, 207.

8. Gold, H., Cattell, McK., Otto, H. L., Kwit, N. T., and Kramer, M. L. A method for the bio-assay of digitalis in humans. J. Pharmacol. exp. Ther. 1942, 75, 196.

9. Friedman, M., and Bine, R., Jr. Employment of the embryonic duck heart for the detection of minute amounts of a digitalis glycoside (lanatoside C). Proc. Soc. exp. Biol. (N. Y.) 1947, 64, 162.

10. Kiliani, H. Ueber $\beta$-Digitoxin. Ber dtsch. chem. Ges. 1885, 28, 1057.

11. Richaud, A. A propos de l'identification de l'Ouabaine et de la Strophantine, et sur un nouveau coractère differential de ces deux glucosides. Travail original. J. Pharm. Chim. (Paris) 1921, 24, 161.

12. Sanchez, J. A. Acerca de una nueva reacción cromatica de la digitoxina, gitoxina, y gitalina y su aplicación al dosaje colorimetrico de dichos glucósidos digitálicos (Nota previo). Sem. méd. (B. Aires) 1934, 2, 399.

13. Tattje, D. H. E. The reaction between digitoxin and 3:5-dinitrobenzoic acid. J. Pharm. (Lond.) 1957, 9, 29.

14. Magalini, S., de Simone, G., and Cinotti, G. A. Metodo spettrofotometrico per la determinazione dei glicosidi cardioattivi. IV. Determinazione della digitossina in presenza di colesterola. Farmaco, Ed. sci. 1955, 10, 510.

15. Sjoerdsma, A., and Fischer, C. S. The fixation of radioactive digitoxin by isolated hearts. Circulation $1951,4,100$.

16. Fischer, C. S., Sjoerdsma, A., and Johnson, R. The tissue distribution and excretion of radioactive digitoxin; studies on normal rats and cats and rats with dietary-induced myocardial lesions. Circulation 1952, 5, 496.

17. Okita, G. T., Talso, P. J., Curry, J. H.. Jr., Smith, F. D., Jr., and Geiling, E. M. K. Blood level studies of $\mathrm{C}^{14}$-digitoxin in human subjects with cardiac failure. J. Pharmacol. exp. Ther. 1955, $113,376$.

18. Hilton, J. G. A polarographic determination of digitoxin. Science 1949, 110, 526.

19. Hilton, J. G. A polarographic method for the determination of digitoxin and gitoxin and its application to pharmacological studies. J. Pharmacol. exp. Ther. 1950, 100, 258.

20. Friedman, M., St. George, S., and Bine, R., Jr. The behavior and fate of digitoxin in the experimental animal and man. Medicine (Baltimore) 1954, 33, 15.

21. Friedman, M., Byers, S. O., and Bine, R., Jr. Rate of disappearance of digitoxin from the blood of man after its parenteral administration. Fed. Proc. $1951,10,46$. 
22. Friedman, M., Bine, R., Jr., and Byers, S. O. Urinary excretion of digitoxin in the rat. Proc. Soc. exp. Biol. (N. Y.) 1949, 71, 406.

23. Friedman, M., and Bine, R., Jr. A study of the rate of disappearance of a digitalis glycoside (lanatoside C) from the blood of man. J. clin. Invest. 1949, 28, 32.

24. Friedman, M., Byers, S. O., Bine, R., Jr., and Bland, C. Renal excretion of digitoxin in man following oral administration. Proc. Soc. exp. Biol. (N. Y.) 1949, 72, 468.

25. Friedman, M., Bine, R., Jr., Byers, S. O., and Bland, C. The renal excretion of digitoxin in the normal subject after single and continuous administration of the drug. Circulation 1950, 2, 749.

26. St. George, S., Bine, R., Jr., Friedman, M., and Bland, C. Renal excretion of digitoxin in the rabbit and dog. Proc. Soc. exp. Biol. (N. Y.) 1951, 78, 504.

27. Friedman, M., St. George, S., Bine, R., Jr., Byers, S. O., and Bland, C. Deposition and disappearance of digitoxin from the tissues of the rat, rabbit, and dog after parenteral injection. Circulation 1952, 6, 367 .

28. St. George, S., Bine, R., Jr., and Friedman, M. The role of the liver in excretion and destruction of digitoxin. Circulation 1952, 6, 661 .

29. Friedman, M., St. George, S., Bine, R., Jr., and Byers, S. O. The renal excretion of digitoxin in the acute and chronic cardiac patient. Circulation $1952,6,853$.

30. St. George, S., Friedman, M., and Ishida, T. The renal excretion of digoxin in the normal young subject. J. clin. Invest. 1958, 37, 836.

31. Geiling, E. M. K., Kelsey, F. E., Ganz, A., Walaszek, E. J., Okita, G. T., Fishman, S., and Smith, L. B. Biosynthesis of radioactive medicinally important drugs with special reference to digitoxin. Trans. Ass. Amer. Phycns 1950, 63, 191.

32. Okita, G. T., Gordon, R. B., and Geiling, E. M. K. Placental transfer of radioactive digitoxin in rats and guinea pigs. Proc. Soc. exp. Biol. (N. Y.) 1952, 80, 536.

33. Okita, G. T., Kelsey, F. E., Talso, P. J., Smith, L. B., and Geiling, E. M. K. Studies on the renal excretion of radioactive digitoxin in human subjects with cardiac failure. Circulation 1953, 7, 161.

34. Okita, G. T., Talso, P. J., Curry, J. H., Jr., Smith, F. D., Jr., and Geiling, E. M. K. Metabolic fate of radioactive digitoxin in human subjects. J. Pharmacol. exp. Ther. 1955, 115, 371.
35. Harvey, S. C., and Pieper, G. R. Intracellular distribution of digitoxin- $\mathrm{C}^{14}$ in the heart. J. Pharmacol. exp. Ther. 1955, 114, 14.

36. Okita, G. T., Plotz, E. J., and Davis, M. E. Placental transfer of radioactive digitoxin in pregnant women and its fetal distribution. Circulat. Res. 1956, 4, 376.

37. Spratt, J. L., and Okita, G. T. Subcellular localization of radioactive digitoxin. J. Pharmacol. exp. Ther. 1958, 124, 115.

38. Ashley, J. J., Brown, B. T., Okita, G. T., and Wright, S. E. The metabolites of cardiac glycosides in human urine. J. biol. Chem. 1958, 232, 315.

39. Shapiro, E. Proc. Symp. on Tritium in Tracer Applications. Boston, Sheldon Press, 1958.

40. Rothchild, E., Ed. Proc. Symp. on Advances in Tracer Applications of Tritium. Boston, Sheldon Press, 1959.

41. Pinson, E. A., and Langham, W. H. Physiology and toxicology of tritium in man. J. appl. Physiol. 1957, 10, 108.

42. Gonzalez, L. F., and Layne, E. C. Unpublished observations.

43. Gisvold, O., and Wright, S. E. Enzymatic decomposition of digitalis glycosides. J. Amer. pharm. Ass., sci. Ed. 1957, 46, 535.

44. Jensen, B. K. Paper chromatography of cardiac glycosides and aglycones from Digitalis purpurea. Acta pharmacol. (Kbh.) 1953, 9, 99.

45. Brown, B. T., Ranger, D., and Wright, S. E. The excretory products of lanatoside $\mathrm{C}$ and digitoxin in the rat. J. Pharmacol. exp. Ther. 1955, 113, 353.

46. Shepheard, E. E., Thorp, R. H., and Wright, S. E. The excretory products of digoxin in the rat. J. Pharmacol. exp. Ther. 1954, 112, 133.

47. Martin, J. F., and Wright, S. E. The metabolism of acetyl digitoxin in the rat. J. Pharmacol. exp. Ther. 1960, 128, 329.

48. Cox, E., and Wright, S. E. The hepatic excretion of digitalis glycosides and their genins in the rat. J. Pharmacol. exp. Ther. 1959, 126, 117.

49. Maximum permissible body burdens and maximum permissible concentrations of radionuclides in air and in water for occupational exposure. Washington, D. C., Natl. Bureau of Standards, Handbook 69, 1959.

50. Sinex, F. M. Opening remarks in Proc. Symp. on Tritium in Tracer Applications, E. Shapiro, Ed. Boston, Sheldon Press, 1958, p. 1. 